\title{
Improving performance measurement efficiency in public service using lean six sigma methodology
}

\author{
Purnawan Adi Wicaksono*, Heru Prastawa, Ghabyanza Pitaloka, and Nurana Putri \\ Industrial Engineering Department, Diponegoro University, Indonesia
}

\begin{abstract}
This research aims to conduct performance measurement efficiency in government and recommends an improvement to reduce the delay of submitting Functional Worksheet (FW) through Lean Six Sigma methodology. At recent system, the causes of delay in submitting FW are human factors i.e. the employee's negligence and technical factor i.e. duplication work in inputing data. The employee's performance measurement takes many times so that the leader can evaluate the employee's FW after 35 days and 195 minutes. In this research, Web-Based Functional Worksheet Information System was designed as the result of the improvement stage of Lean Six Sigma. The Web-Based Functional Worksheet Information System improved the recent system in submitting FW and reduced the time of finishing the submitting FW. Moreover, the leader could evaluate the employee's FW in a day.
\end{abstract}

\section{Introduction}

From year to year, the growth of service sectors became higher. Therefore, many organizations started to pay attention to the efficiency of operations in term of improvement [1]. This improvement covered several matters such as product improvement (goods and/or services), defects or service errors reducing, more compact operation system, good employees' skills, and others [2].

Government as the public service provider was under the pressure to improve the efficiency and the quality of public service [3]. It still attempts to improve the quality. Nowadays, most people rarely give positive assessment to the public service performance [4]. Government should initiate the improvement to remove the negative image of community by the effective movement. Therefore, it is important for public service organization to measure its performance systematically and consistently to improve its organizational management and its community satisfaction of the given services.

*Corresponding author: purnawan@undip.ac.id 
Lean Six Sigma concept can be used by an organization to increase the performance as well as the efficiency as it still considers the quality, rate, customer satisfaction, and costs [5]. Lean Six Sigma, a combination between lean and six-sigma, is defined as the business philosophy to identify and eliminate the waste or non-value added activities through continuous improvement [6]. This research tries to apply Lean Six Sigma methodology to improve the process quality in governmental sector.

\section{Literature Review}

On previous research, Lean Six Sigma was used as a method to shorten the process, to improve the service quality, and to decrease the dissatisfying services in the case of IT help-desk service [7]. The result was that the average time of service process in IT helpdesk service was reduced to 79.5 minutes or $47.5 \%$ after the previous performance. Total Quality Management (TQM) and Lean Six Sigma were used to improve the quality and the punctuality of local government services[8]. Local Financial Department might significantly reduce the times to process wages, purchases and accounts' payable, accounts' receivable and monthly reconciliation. The times to process wages, purchases and accounts' payable, accounts' receivable, and monthly reconciliation process were reduced to $60 \%$, $40 \%, 90 \%$, and $87 \%$ respectively. Lean Six Sigma aimed to illustrate its application in call center of a services company[5]. The results were the increase of first call resolution ratio, decrease of operator earnings, and streamline process. Lean Six Sigma methodology was used well to improve the surgery room efficiency in an academic children hospital [9]. Lean Six Sigma methodology could be applied appropriately in UK public sector to get the benefits and better return of investment[10]. Lean Six Sigma methodology is a good tool to be applied in all public organizations to make the efficient and effective processes [11].

After the previous researches, this paper aims to conduct an efficient measurement process of government position and recommends improvements in order to reduce the delay of submitting Functional Worksheet (FW) through Lean Six Sigma method.

\section{Methodology}

The case study focused on the goverment performance measurement in Boyolali, Central Java, Indonesia. In recent system, each employee must measure his/her performance by writing his/her efficiency in the Functional Worksheet paper. The Functional Worksheet paper should be submitted to the Financial and Asset Management Sub Division at least on the $5^{\text {th }}$ of the following months. However, more than $50 \%$ of employees did not submit the Functional Worksheet papers on time. It was caused by the human factor i.e. the employees' negligence. After that, it was verified. The Financial and Asset Management Sub Division should manually re-input the results to Microsoft Excel which would take more time. The input of the same data showed that the recent system was not efficient. Lean Six Sigma containing DMAIC (Define, Measure, Analyze, Improve, Control) was used to improve the process efficiency of government employees' performance. Lean Six Sigma methodology help us to analyze the performance measurement process and to improve the performance measurement efficiency.

\section{Result and Discussion}




\subsection{Definition}

The recent performance measurement process was analyzed which would be accurately improved and determine anything needed for the better process. The performance measurement efficiency was analyzed by using SIPOC chart (Suppliers, Inputs, Process, Outputs, and Customers) in Figure 1.

Three types of waste were identified in the process as follows:

- Waiting, the delay of submitting Functional Worksheet caused the Financial and Asset Management Sub Division waiting when it must input the data.

- Transportation, there was an unnecessary stage of transporting the Functional Worksheet since it is a non-value added activity.

- Defect, the Financial and Asset Management Sub Division inputted the Functional Worksheet manually, so its error possibility was high.

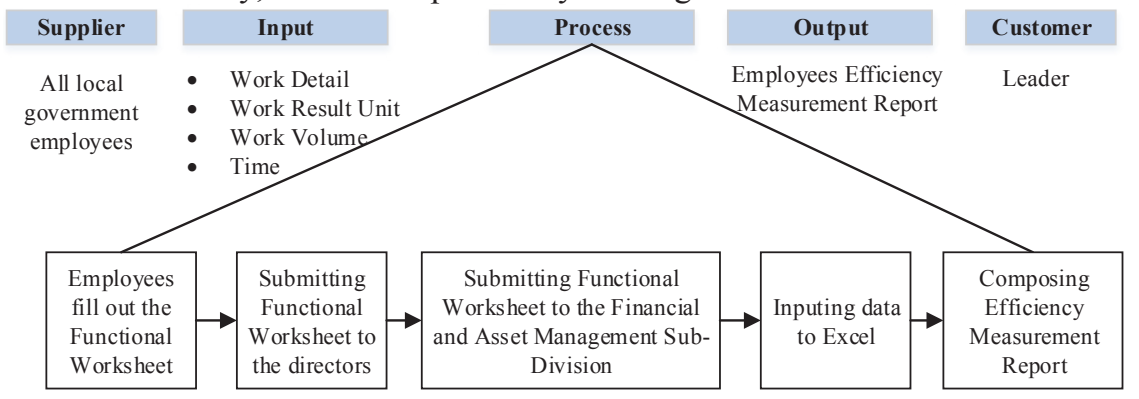

Fig. 1. SIPOC Chart

\subsection{Measurement}

The recent performance was measured to be compared with the target. The writers used Value Stream Mapping to describe the value added and non value added activities for the customers, so the significance and appropriate improvement could be implemented (Figure 2 ). At this time, the leader might evaluate the employees' efficiency value after 35 days and 195 minutes. The activity details of recent performance measurement can be seen in table 1 . Table 1 describes the mapping process that consists of Value Added (VA) and Non Value Added (NVA), Input (I) and Output (0) item, Controllable (C) and Uncontrollable (U).

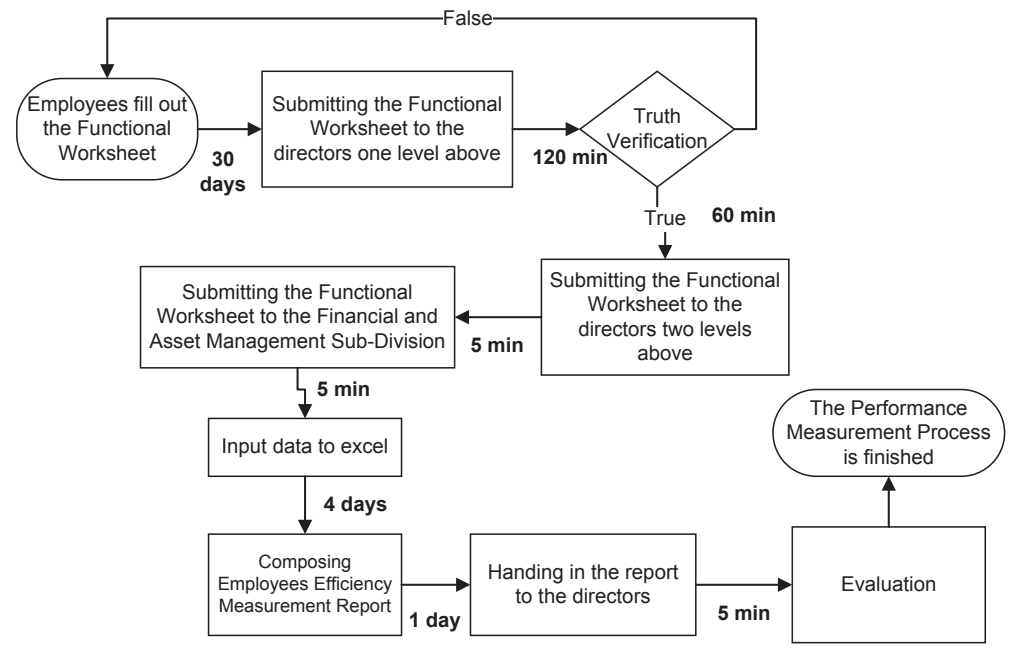

Fig. 2. Previous Value Stream Mapping System 


\subsection{Analysis}

The data was analyzed and determined the possible improvement. The cause and effect chart was used to analyze the problem (Figure 3). The purpose of this chart is to identify the various potential causes of the problem.

Table 1. Process Mapping

\begin{tabular}{|c|c|c|c|c|}
\hline Process Mapping & $\begin{array}{l}\text { VA/ } \\
\text { NVA }\end{array}$ & Input/output items & $\mathbf{I} / \mathbf{O}$ & $\mathbf{C} / \mathbf{U}$ \\
\hline \multirow{4}{*}{$\begin{array}{l}\text { Employees fill out the } \\
\text { Functional Worksheet }\end{array}$} & VA & Functional Worksheet Form & I & $\mathrm{C}$ \\
\hline & VA & $\begin{array}{l}\text { The employees write down the activity } \\
\text { details, work result unit, work volume, } \\
\text { time }\end{array}$ & $\mathrm{I}$ & $\mathrm{C}$ \\
\hline & VA & Measuring the Functional efficiency & I & $\mathrm{C}$ \\
\hline & VA & $\begin{array}{l}\text { Employees Functional Worksheet which } \\
\text { has been filled out }\end{array}$ & $\mathrm{O}$ & $\mathrm{C}$ \\
\hline \multirow{2}{*}{$\begin{array}{l}\text { Submitting the Functional } \\
\text { Worksheet to the leader } \\
\text { one level above }\end{array}$} & VA & Functional Worksheet of each employee & $\mathrm{I}$ & $\mathrm{C}$ \\
\hline & VA & $\begin{array}{l}\text { Functional Worksheet collected based on } \\
\text { the department }\end{array}$ & $\mathrm{O}$ & $\mathrm{C}$ \\
\hline \multirow{2}{*}{$\begin{array}{l}\text { Functional Worksheet } \\
\text { verification }\end{array}$} & VA & Functional Worksheet of each employee & I & $\mathrm{C}$ \\
\hline & VA & Functional Worksheet verification & $\mathrm{O}$ & $\mathrm{U}$ \\
\hline \multirow{2}{*}{ Revision } & VA & Functional Worksheet Form & I & $\mathrm{C}$ \\
\hline & VA & Functional Worksheet Revision & $\mathrm{O}$ & $\mathrm{C}$ \\
\hline \multirow{2}{*}{$\begin{array}{l}\text { Submitting the Functional } \\
\text { Worksheet to the leader } \\
\text { two levels above }\end{array}$} & NVA & $\begin{array}{l}\text { Employees Functional Worksheet on a } \\
\text { particular department }\end{array}$ & I & $\mathrm{C}$ \\
\hline & NVA & $\begin{array}{l}\text { Functional Worksheet collectedbased on } \\
\text { the department }\end{array}$ & $\mathrm{O}$ & $\mathrm{C}$ \\
\hline \multirow{2}{*}{$\begin{array}{l}\text { Submitting the Functional } \\
\text { Worksheet to the } \\
\text { Financial and Asset } \\
\text { Management Sub } \\
\text { Division }\end{array}$} & VA & Functional Worksheet of each employee & $\mathrm{I}$ & $\mathrm{C}$ \\
\hline & VA & The Functional Worksheet is submitted & $\mathrm{O}$ & $\mathrm{C}$ \\
\hline \multirow{2}{*}{ Inputing data to Excel } & NVA & Functional Worksheet of each employee & I & $\mathrm{C}$ \\
\hline & NVA & Functional Worksheet is input to Excel & $\mathrm{O}$ & $\mathrm{C}$ \\
\hline \multirow{2}{*}{$\begin{array}{l}\text { Composing efficiency } \\
\text { measurement report }\end{array}$} & VA & The employees efficiency value & I & $\mathrm{U}$ \\
\hline & VA & Efficiency Measurement Report & $\mathrm{O}$ & $\mathrm{C}$ \\
\hline \multirow{2}{*}{$\begin{array}{l}\text { Submitting report to the } \\
\text { leader }\end{array}$} & VA & Efficiency Measurement Report & I & $\mathrm{C}$ \\
\hline & VA & $\begin{array}{lll}\begin{array}{l}\text { Efficiency Measurement } \\
\text { submitted to the leader }\end{array} & \text { Report is } \\
\end{array}$ & $\mathrm{O}$ & $\mathrm{C}$ \\
\hline \multirow[b]{2}{*}{ Evaluation } & VA & Efficiency Measurement Report & $\mathrm{I}$ & $\mathrm{C}$ \\
\hline & VA & $\begin{array}{l}\text { The leader and evaluation of the } \\
\text { employees efficiency }\end{array}$ & $\mathrm{O}$ & $\mathrm{U}$ \\
\hline
\end{tabular}

\subsection{Improvement}

The improvement aims to make changes in the process by eliminating defects, waste, and cost. From the previously mentioned problems, it could be found that the performance measurement system was not well integrated yet. There were duplication works in inputing data. A web-based information system was designed which might improve the performance measurement process (Figure 4). It is dynamic application-a combination between database and world wide web - to compact the process so the data processing and distribution become faster and easier [12]. By the web-based information system, the leader may evaluate the employees' performance on the day (Figure 5). In table 2, comparison between the recent system and the web-based information system were presented. 


\subsection{Control}

The control is conducted to improve the process capabilities. One way in developing the control planning is making the standard operating procedures (SOP) as the guidance of the performance measurement process implementation [7].

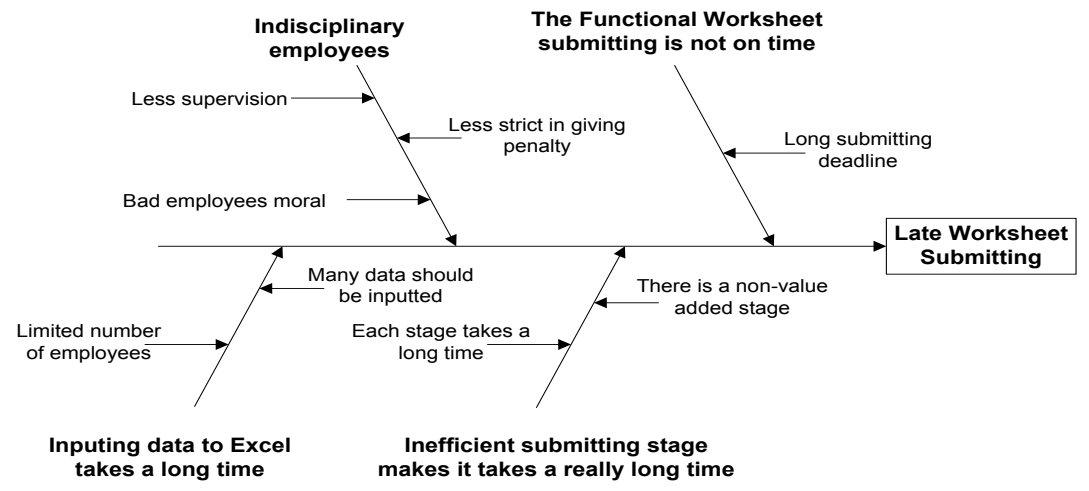

Fig. 3. Fishbone Chart

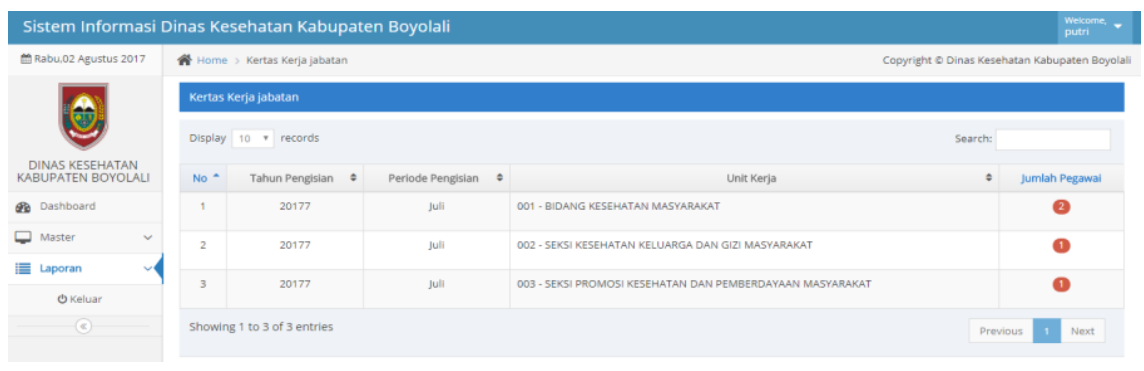

Fig. 4. Image of Information System

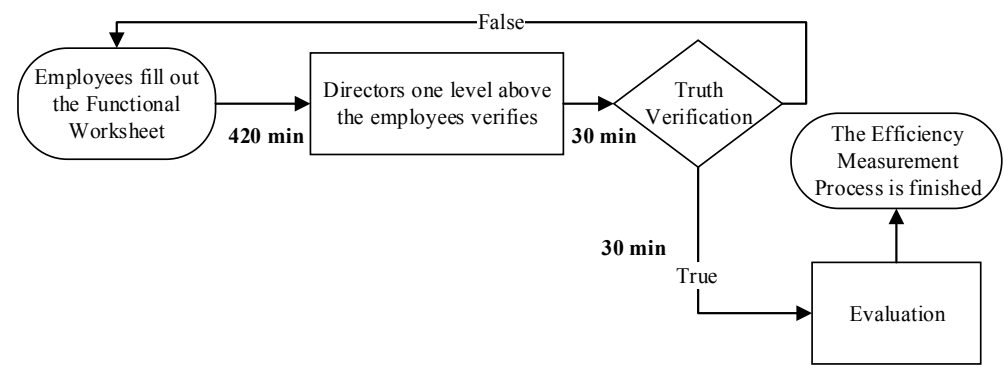

Fig. 5. Value Stream Mapping of Recent System

Table 2. Time Comparison between the Recent System and Web-Based Information System

\begin{tabular}{|l|c|c|}
\hline \multicolumn{1}{|c|}{ Comparative Factor } & Recent System & Web-Based Information System \\
\hline Recording and storage media & Microsoft Excel & Database is integrated to the system \\
\hline $\begin{array}{l}\text { Estimated time until the } \\
\text { evaluation }\end{array}$ & $\begin{array}{c}35 \text { days } 195 \\
\text { minutes }\end{array}$ & 1 day \\
\hline
\end{tabular}




\section{Conclusion}

The problem of employees' performance measurement was the delay of submitting the Functional Worksheet. It was caused by the waste and non value added activities. Lean Six Sigma was used to identify and eliminate the waste and non value added activities. Lean Six Sigma used simple method called DMAIC (Define, Measure, Analyze, Improve, Control). The recent performance measurement process takes 35 days and 195 minutes in order to be able to be evaluated. The time of performance measurement can be decreased by implementation of Web-Based Functional Worksheet Information System. Moreover, the leader can evaluate the employees' performance on the day. Further research is to make the appropriate standard operating procedure as the guidance of the performance measurement implementation process.

\section{References}

1. G. H. Cavaness, J.P., \& Mannochehri, "Building Quality into Services.pdf," SAM Adv. Manag. J., 3, 6 (1993).

2. J. R. Evans and W. M. Lindsay, An Introduction to Six Sigma and Process Improvement, Second Edi. Jakarta: Penerbit Salemba Empat, (2014).

3. A. Agus, S. Barker, and J. Kandampully, "An Exploratory Study of Service Quality in the Malaysian Public Service Sector," Int. J. Qual. Reliab. Manag., 24, 2(2007).

4. B. Teeuwen, Lean for the Public Sector. USA: Productivity Press, (2010)

5. A. Laureani, J. Antony, and A. Douglas, "Lean Six Sigma in a Call Centre: a Case Study," Int. J. Product. Perform. Manag., 59, 8 (2010)

6. V. Gaspersz, Lean Six Sigma for Manufacturing and Service Industries. Jakarta: PT. Gramedia Pustaka Utama, (2007).

7. C. Su, "Improving Service Quality by Capitalising on an Integrated Lean Six Sigma Methodology," 2, 1 (2006).

8. S. Furterer and A. K. Elshennawy, "Implementation of TQM and Lean Six Sigma Tools in Local Government: a Framework and a Case Study," Total Qual. Manag. Bus. Excell., 16, 10 (2005).

9. E. P. Tagge, A. S. Thirumoorthi, J. Lenart, C. Garberoglio, and K. W. Mitchell, "Improving operating room efficiency in academic children' s hospital using Lean Six Sigma methodology," J. Pediatr. Surg., 52, 6 (2017)

10. J. Antony and B. Rodgers, "Can Lean Six Sigma make UK public sector organisations more efficient and effective," Int. J. Product. Perform. Manag., 65, 7 (2016)

11. J. Antony, B. Rodgers, and Cudney, "Lean Six Sigma for public sector organizations: is it a myth or reality?," Int. J. Qual. Reliab. Manag., 34, 9 (2017)

12. S. O. Cheung, H. C. H. Suen, and K. K. W. Cheung, "PPMS: A Web-based construction Project Performance Monitoring System," Autom. Constr., 13, 3 (2004) 